\title{
IMPLEMENTATION OF THE LINEN AND LAUNDRY \\ MANAGEMENT POLICY AT MUHAMMADIYAH GAMPING HOSPITAL, YOGYAKARTA
}

\author{
Anisah, Elsye Maria Rosa, Ekorini Listiowati \\ Masters Program in Hospital Management, Universitas Muhammadiyah Yogyakarta
}

\begin{abstract}
Background: The aim of the linen and laundry management policy is to ensure effective linen and laundry management to prevent cross infection between patients, and also to protect staff when handling and transporting laundry. This study aimed to analyze the implementation of the linen and laundry management policy at Muhammadiyah Gamping Hospital, Yogyakarta.

Subjects and Method: This was a qualitative case study carried out at Muhammadiyah Gamping Hospital, Yogyakarta. A sample of 11 informants was selected for this study, consisting of laundry or linen unit employees, linen supervisor, Infection Prevention and Control (PPI) chairman, and household manager. The study theme was implementation of linen and laundry management. The data were collected by questionnaire, in-depth interview, and direct observation.

Results: Workload of linen and laundry management was heavy. The linen management was good, although only 6 (55\%) employees had good knowledge regarding linen management. As much as $20 \%$ employees did not use protective wear when collecting and washing linen. They did not use closed clean trolley. Management perspective on linen laundry management was good.

Conclusion: Compliance of linen employees with the standard operational procedure was suboptimal. Workload was heavy. There is a need to add more employees in the linen and laundry management.
\end{abstract}

Keywords: linen management, infection prevention and control

\section{Correspondence:}

Anisah. Masters Program in Hospital Management, Universitas Muhammadiyah Yogyakarta, Jl. Lingkar Selatan,Tamantirto, Kasihan, Bantul, Yogyakarta.

Email: anisah.mmr2014@gmail.com. Mobile: 081225284868 